\title{
Twenty years of transparency research
}

JAMES E. ALT, Ph.D.

Conference keynote*

https://doi.org/10.3326/pse.43.1.2

* Received: January 16, 2019

Accepted: January 18, 2019

\begin{abstract}
A keynote speech given at the conference "Public Sector Economics 2018 - Fiscal openness: transparency, participation and accountability in fiscal policies" organized by the Institute of Public Finance, International Budget Partnership and Friedrich-Ebert-Stiftung in Zagreb on October 26, 2018.
\end{abstract}

\section{James E. ALT}

Frank G. Thomson Professor of Government, Harvard University, Institute for Quantitative Social Science, 1737 Cambridge Street, CGIS Knafel 307, Cambridge, MA 02138, USA

e-mail: jalt@iq.harvard.edu

ORCiD: 0000-0002-9218-8164 


\section{INTRODUCTION: HOW DID FISCAL TRANSPARENCY REACH \\ THE ACADEMIC AGENDA?}

With applications in financial, regulatory, monetary, and fiscal policy, and with the World Bank, IMF, OECD, and many other NGOs advising on best practices, fiscal transparency has become a major theme of contemporary research in political economy and public administration. It was not always so. Even though the connection between transparency and corruption prevention was understood by the ancient Athenians, the connection with democracy at least since 1689, and the importance of bookkeeping and auditing practices in economic development even earlier, there was little academic interest in the causes and consequences of transparency. An important stimulus to academic thought was Holmström (1979), with $10,000+$ citations. One could weave a narrative through three subsequent streams of analysis - institutions, corruption, and debt - in academia with real-world developments from Watergate, the US Foreign Corrupt Practices Act, the founding of Transparency International, some aggressive lobbying by US firms, to the FCPA Amendments and OECD Convention of 1997-98. However, even though the 1990s saw increased attention to information, opportunism, and verification and the path-breaking publication of Mauro (1995, also 10,000+ citations), there was essentially no mention of "transparency". It is no longer so.

Today, according to the US Department of State (2017), fiscal transparency is a critical element of effective public financial management, one that helps in building market confidence and underpins economic sustainability. Fiscal transparency also fosters greater government accountability by providing a window into government budgets for citizens, helping them to hold their leadership accountable and facilitating better-informed public debate. These pronouncements may be somewhat exaggerated, but around the literature one finds similar claims, that transparency promotes not only stability, sustainability, and credibility, but even trust. These claims have some truth in them, but overall the evidence in support of them is mixed. Our goal in this note is to look at twenty years of transparency research and highlight what is known and what is new.

A common view of fiscal transparency twenty years ago was that budgets that included numerous special accounts and failed to consolidate all fiscal activity into a "bottom line" were too complex to comprehend and thus not transparent. More complete definitions contained observability in two senses: that information provided should be accurate, comprehensive, timely, accessible, and verified, and that there should be receipt (and maybe comprehension) of information by the public, an argument at least as old as Bentham, for whom "publicity" was a central concept. In these senses, transparency requires state capacity to calculate and technology to make information accessible and forbids it to be withheld. Acquiring and understanding information has become more costly with complexity and contested components like risk and sustainability, especially for receivers who need more ability to "read". For accountability, receivers need the capacity (sophistication) to use data: this is more of an issue with voters than markets. Most 
recently transparency has come to include rights of public participation in decisions: this is very different.

In January 1998 George Kopits and Jon Craig wrote "Transparency in Government Operations", an IMF Occasional Paper. It represents a turning point, even though (amazingly to me), it has had only 500 citations in the twenty years since. Their argument was straightforward: timely publication of a clearly presented budget document (i.e., transparency) allowed the market to evaluate government's intentions, key to the market imposing discipline on government. As Kopits and Craig saw it, this would increase political risk (i.e., impose a cost on incumbent politicians of running unsustainable policies). Moreover, transparent public financial accounting would allow comparing budgeted and actual financial operations, and thus facilitate achievement of basic macroeconomic policy objectives and increase the productivity of public expenditure. More generally, boldly, transparency would thus increase trust in government. For evidence (mostly narrative), they alleged strong a priori reasons that transparency improves economic performance, arguing that it was a precondition for sustainability, accountability, and corruption prevention. Although citation was sparse, others quickly picked up the theme: within a year Vito Tanzi published "Corruption Around the World: Causes, Consequences, Scope, and Cures" in the IMF Staff Papers and Bill Easterly's "When is fiscal adjustment an illusion?" appeared a few months later. It seemed as though the rush to data and empirical research to examine these claims was on.

\section{THE FIRST DECADE AND BEYOND}

By 2006 NGOs had produced a flood of indicators. The IMF had managed to get half its members to do a ROSC (Report on Standards and Codes) based on its 1998 Code and Transparency manual. The OECD's country surveys produced a report on best practices in 2002. The first Open Budget Index, prepared with the opinions of independent experts rather than national government officials, came out in 2006. Nevertheless, limited empirical work appeared. What did mostly assumed that "More information is better" (citing Holmström) and focused on moral hazard and career concerns. An early model by Ferejohn (1999) assumed all politicians were motivated only by rents (no screening effects) and made transparency endogenous by allowing the agent (politician) to choose the observability of her actions. Politicians could thus commit to more effort (more transparency), receiving higher tax-based compensation than if action were completely hidden. The result: under some conditions, transparency increases incumbent retention and fiscal scale by reducing the negative impact of tax increases.

An early empirical paper employing this approach was Alt, Lassen, and Skilling (2002) on governor approval in opinion polls in US states. They collected nine indicators from published sources (based on surveys of civil servants) on whether states were committed to GAAP, using a binding independent revenue forecast, including performance results, voting the budget in a single bill, and so on. They showed that a higher transparency score was associated with greater state fiscal 
scale and higher governor approval ratings. Alt, Lassen, and Rose (2006) tackled the obvious endogeneity (joint causation) problem with earlier results by collecting an interview-based retrospective panel dataset for 1972-2002, since replicated and still requested. These data showed that political competition was associated with greater transparency (subsequently independently confirmed), political polarization was associated with lower transparency, and that fiscal imbalance was associated with increases in transparency (evident in case studies but less robust in the quantitative analysis). Other papers (Alt and Lassen, 2006a, 2006b, 2008; Alt and Lowry, 2010) showed that transparency was less successful in reducing deficits when competitive pressures of the electoral calendar increased, that competitive institutions conditioning transparency were associated with lower corruption, that the US municipal bond market's response to state deficits was conditioned by institutional transparency, and that in the US, electoral support (vote and frequency of electoral defeat) revealed that raising taxes transparently hurts incumbent governors less.

Theory in the early years pushed to go beyond the sole focus on moral hazard, largely (to sum up a complex subject) because of a growing awareness that with incomplete incentives, results become more complicated and conditional. For example, in models of voting to re-elect, discipline and selection have opposing welfare effects via equilibrium behavior if there are good and bad types (Besley, 2006). A flirtation with yardstick competition helped a little. Others raised the possibility of "too much sunshine" (Hood and Heald, 2006) or the wrong information structure (Prat, 2005). Though it was clear that there remained a big role for institutional analysis, causality (to say nothing of measuring the relative frequency of types) often appeared ambiguous. In other ways there were still missing aspects of transparency. At most we were measuring access to information as opposed to its quantity and quality, justification, or verifiability, and even access was only measured by communications media freedom and penetration (newspapers and television, not yet the impact of the Internet).

There was also much more empirical work by other scholars, and the field has expanded rapidly in recent years. De Renzio and Wehner (2017) provide an excellent review; there are other reviews (cited in their sources) but this one is most useful for the theme of this Note. They conclude that over a number of diverse papers the origins of transparency do seem to involve fiscal stress and political competition, but that there are only mixed macro results on spending, deficits, and debt. Results seem to be conditional on the presence of mechanisms of dissemination to lower acquisition costs, like the availability of a free press. Transparency appears good for LDC investment, but whether it is also good for development is at best a "maybe". On publicity (the impact of actual receipt of information), there are important results on audits, media freedom, and maybe penetration. Since fresh perspectives are helpful, we will look more closely at some of these below. Finally, de Renzio and Wehner find that participation affects the distribution rather than the magnitude of spending, as well as public satisfaction or sense of 
empowerment with process, but remain appropriately (in my view) skeptical about research cumulation, strength, and impact.

\section{AND AFTER}

"Traditional" data sources expanded enormously as "practitioners" provided new data sources. NGOs have been hyperactive: the World Bank is creating datasets on Government Statistical Capacity and has launched the Budget Transparency Initiative, the International Budget Project regularly releases new versions of the Open Budget Index, and the IMF in 2017 revised definitions of net and gross debt in its World Economic Outlook database while joining the World Bank and other institutions in establishing PEFA, the Public Expenditure and Financial Accountability framework. Several of these institutions and others form GIFT, the Global Initiative for Fiscal Transparency, which among other things provides an online Open Fiscal Data Package. Then there is the Extractive Industries Transparency Initiative; also, Eurostat provides the Financial Transparency system to enable examination of EU funding recipients via online searches. There are also two major "private" datasets available: Hollyer, Rosendorff and Vreeland (2018), and Williams (2014). Both make heavy use of the World Bank's World Development Index data, gauging a country to be non-transparent to the extent that its data do not appear in the WDI. Williams uses more sources, but the main contribution of both is to make data available for more countries in more years, shifting the focus to developing countries (in particular middle-income autocracies) and state capacity and willingness to disclose information. Replicating existing results for advanced countries (e.g. Alt, Lassen, and Wehner, 2014) does not apparently provide a great deal of new information.

More importantly, conceptual and measurement innovations abound. There have been a number of creative new looks. Here I will highlight just a few: new ways to approach freedom of information, including performance evaluation, getting closer to the details of accurate accounting, including public participation. Many of these areas have benefitted from the increasing use of experiments, especially in economics but also to some extent in political science and public administration.

One very creative new look was Berliner's (2014) examination of the passage of Freedom of Information Acts (FOI laws) that can increase the cost to politicians of corrupt acts, especially in democracies. He notes the conundrum that electoral promises to increase transparency were rarely or at best slowly kept, but many laws were passed regardless, almost all new laws since 1995 in developing countries. The argument is that this is an insurance or hand-tying game, that the laws pass when a governing party fears losing power, or in some way holds power but does not expect to keep it. The argument is supported by narratives from countries such as Japan, South Korea, Mexico, Canada, Guinea, Niger, and Nigeria. These and subsequent related results recall some of the original Alt-Lassen-Rose findings on the importance of competition as a conditioning context. Increases also appear to be sustained, which implies that models involving commitment are reasonable. 
The PEFA (2016) framework incorporates transparency (how well informed on finances the public is kept) as a pillar, joining it to accountability and suggesting standards of credibility: aggregate accuracy, consistency over time, and compositional invariance of financial indicators. Preliminary results nevertheless seem familiar. Expenditure executed slightly better on average than revenue; lack of transparency is mostly due to economic shocks, challenges in revenue forecasting (poor forecasts), the use of supplementary expenditures, and the unreliability of donor funds. But a great deal of data will become available, both local (the BTI) and national. Theory to shape expectations would help: what is needed is a model in which incumbents have distinct policy preferences and are held accountable for the difference between observed outputs and prior expectations. There is one: the Meirowitz (2007) model of accountability assumes incumbents belong to parties with distinct policy preferences and have private information about feasibility constraints on policy. One could incorporate transparency by allowing voters' information about feasibility constraints to vary but so far I have not seen this done.

Creative accounting is not new; fiscal illusion and false "adjustment" have been studied for years. Much of the recent transparency literature builds on re-election and election-timing motivating government obfuscation and concealment (see Hudspeth et al., 2015; most recently Repetto, 2018). Questions abound. How important is election-timing in government accounting choices? Is accrual accounting manipulation-proof? In world where fiscal policy is increasingly focused on second-order, complex rules with contested meanings, what does this do to the need for transparency? Different accounting systems treat assets and liabilities differently; Alt, Lassen and Wehner (2014) show the need to dig deep into the accounting components to detect manipulation. More information on variation in public sector accounting standards will be very helpful: the information concerning 14 countries recently made available (Brusca et al., 2015) is a good start. Fund-shifting to evade rules, delays in passing and releasing data on budgets and other comprehensive financial reports, treating public-private partnerships as non-public: all need further study. There is a burgeoning area for transparency studies with new applications all the time to corporate governance and executive pay.

Finally, there is some indication that participation has different effects from older measures of transparency. It may be that mandating participation has more impact on targeting and distribution of expenditures, by both geography and gender, on public satisfaction with outcomes and process, and on citizen (especially women's) sense of empowerment. But participation's impact also can be frustrated by entrenched gatekeepers. Competent participation is highly information dependent and can require some sophistication to understand how best to use the information. It is thus also vulnerable to strategic information-providing, particularly when source credibility is hard to assess, as on the Internet. 
Increasingly we see that transparency alone is often not the answer. The literature on corruption reminds us that enforcement power often has to be added to free transmission of information to make transparency effective. For instance, publicized random audits did expel some corrupt mayors in Brazil (Ferraz and Finan, 2008) but this happened only in conjunction with active local radio, in contexts where re-election was possible, so losing was a potential penalty. In contrast, Olken's (2007) Indonesian audits were ineffective because no penalties were possible, not having been fixed by public participation. The need for competence and sophistication grows as transparency comes to be seen as a cheaper substitute for enforcement. As Olken put it, "Transparency and publicity are powerful tools but only if combined with grassroots organizations with the incentive and the competence to use the information provided."

What else have we learned? First, I would say: recently, to have more respect for complexity, a heightened awareness of tradeoffs, and the importance of more attention to institutional detail. The general problem of the endogeneity of institutions has only rarely been attacked, so the growth of experiments is very helpful - but not definitive, at least in part because the experimental work suggests that "local" is important. Second, we have seen how the efficacy of transparency depends on social and political context: we see this in comparing democracies with autocracies, the inconsistent effects of resource dependence, and how low levels of literacy/empowerment make information less actionable. Third, we learn again to respect unintended consequences like the threat of authoritarian conformity and popular disillusionment and the danger of negative externalities, particularly around the Internet. All in all, even though the World Bank (2016) is still a cheerleader, it is just not as easy as the State Department said: what works best when there are multiple agents? Making information actionable (by public or prosecutors) is challenging. Technology accentuates the impact of transparency, but cuts both ways, as in the case of Internet information provision: while more information is provided less verification is possible.

Worse, participation in polarized contexts in the presence of motivated reasoning creates a novel tradeoff. Motivated reasoning (Lodge and Taber, 2000) describes a tendency to seek information that confirms prior beliefs (i.e., a confirmation bias), to view evidence consistent with prior opinions as stronger or more effective (prior-attitude effect), and to dismiss evidence inconsistent with prior opinions, regardless of objective accuracy (disconfirmation bias). The result: with information in conflict, more information means less updating and no fact-checking. With polarization, this means that ramping up transparency is not the solution with nonrandom exposure to messages. Expert credibility requires consensus facts but strategic media pundits, partisan think tanks, and, even more, interest groups raise doubts. More sophistication is needed to connect action, effects, and benefits to the individual. It seems likely that this could once again make an intermediate level of transparency optimal. 


\section{REFERENCES}

1. Alt, J. and Lassen, D., 2006a. Transparency, political polarization, and political budget cycles in US states. American Journal of Political Science, 50(3), pp. 530-550. https://doi.org/10.1111/j.1540-5907.2006.00200.x

2. Alt, J. and Lassen, D., 2006b. Fiscal transparency, political parties and debt in OECD countries. European Economic Review, 50(6), pp. 1403-1439. https:// doi.org/10.1016/j.euroecorev.2005.04.001

3. Alt, J. and Lassen, D., 2008. Political and judicial checks on corruption: evidence from American state governments. Economics \& Politics, 20(1), pp. 33-61.

4. Alt, J. and Lowry, R., 2010. Transparency and accountability: empirical results for US states. Journal of Theoretical Politics, 22(4), pp. 379-406. https://doi.org/10.1177/0951629810375641

5. Alt, J., Lassen, D. and Rose, S., 2006. The causes of transparency: evidence from the American states. IMF Staff Papers, No. 53 (Special issue), pp. 30-57.

6. Alt, J., Lassen, D. and Skilling, D., 2002. Fiscal transparency, gubernatorial popularity, and the scale of government: evidence from the states. State Politics and Policy Quarterly, 2(3), pp. 230-250. https://doi.org/10.1177/ 153244000200200302

7. Alt, J., Lassen, D. and Wehner, J., 2014. It isn't just about Greece: domestic politics, transparency and fiscal gimmickry in Europe. British Journal of Political Science, 44(4), pp. 707-716. https://doi.org/10.1017/S0007123414000064

8. Berliner, D., 2014. The political origins of transparency. The Journal of Politics, 76(2), pp. 479-449. https://doi.org/10.1017/S0022381613001412

9. Besley, T., 2006. Principled Agents? Oxford: Oxford University Press.

10. Brusca, I. [et al.] (eds.), 2015. Public Sector Accounting and Auditing in Europe.London: Palgrave Macmillan. https://doi.org/10.1057/9781137461346

11. de Renzio, P. and Wehner, J., 2017. The impacts of fiscal openness. World Bank Research Observer, 32(2), pp. 185-210.

12. Ferejohn, J., 1999. Accountability and authority: toward a theory of political accountability In: A. Przeworski, S. Stokes and B. Manin (eds.). Democracy, Accountability and Representation. Cambridge: Cambridge University Press, pp. 31-53. https://doi.org/10.1017/CBO9781139175104.005

13. Ferraz, C. and Finan, F., 2008. Exposing corrupt politicians: the effects of Brazil's publicly released audits on electoral outcomes. Quarterly Journal of Economics, 123(2), pp. 703-45. https://doi.org/10.1162/qjec.2008.123.2.703

14. Hollyer, J., Rosendorff, B. P. and Vreeland, J., 2018. Information, Democracy, and Autocracy: Economic Transparency and Political (In)Stability. Cambridge: Cambridge University Press. https://doi.org/10.1017/9781108355100

15. Holmström, B., 1979. Moral hazard and observability. Bell Journal of Economics, 10(1), pp. 74-91. https://doi.org/10.2307/3003320

16. Hood, C. and Heald, D., 2006. Transparency: The Key to Better Governance. Oxford: Oxford University Press. https://doi.org/10.5871/bacad/9780197263839. 001.0001 
17. Hudspeth, N. D. [et al.], 2015. Do troubled times invite cloudy budget reporting? The determinants of general fund expenditure share in U.S. states. Public Budgeting and Finance, 35(4), pp. 68-89. https://doi.org/10.1111/pbaf.12080

18. Kopits, G. and Craig, J., 1998. Transparency in government operations. IMF Occasional Paper, No. 158. Washington: International Monetary Fund.

19. Lodge, M. and Taber, C., 2000. Three steps toward a theory of motivated political reasoning In: A. Lupia, M. McCubbins and S. Popkin (eds.). Elements of Reason: Cognition, Choice, and the Bounds of Rationality. Cambridge: Cambridge University Press, pp. 183-213. https://doi.org/10.1017/CBO9780511805813.009

20. Mauro, P., 1995. Corruption and growth. The Quarterly Journal of Economics, 110(3), pp. 681-712. https://doi.org/10.2307/2946696

21. Meirowitz, A., 2007. Probabilistic voting and accountability in elections with uncertain policy constraints. Journal of Public Economic Theory, 9(1), pp. 41-68. https://doi.org/10.1111/j.1467-9779.2007.00297.x

22. Olken, B., 2007. Monitoring Corruption: Evidence from a Field Experiment in Indonesia. Journal of Political Economy, 115(2), pp. 200-249. https://doi. org/10.1086/517935

23. PEFA, 2016. The PEFA framework. Available at: https://pefa.org/content/ pefa-framework

24. Prat, A., 2005. The wrong kind of transparency. American Economic Review, 95(3), pp. 862-877. https://doi.org/10.1257/0002828054201297

25. Repetto, L. and Rose, S., 2006. The causes of transparency: evidence from the American states. IMF Staff Papers, No. 53 (Special issue), pp. 30-57.

26. Repetto, L. and Skilling, D., 2002. Fiscal transparency, gubernatorial popularity, and the scale of government: evidence from the states. State Politics and Policy Quarterly, 2(3), pp. 230-250. https://doi.org/10.1177/153244000 200200302

27. Repetto, L. and Wehner, J., 2014. It isn't just about Greece: domestic politics, transparency and fiscal gimmickry in Europe. British Journal of Political Science, 44(4), pp. 707-716. https://doi.org/10.1017/S0007123414000064

28. Repetto, L., 2006b. Fiscal transparency, political parties and debt in OECD countries. European Economic Review, 50(6), pp. 1403-1439. https://doi. org/10.1016/j.euroecorev.2005.04.001

29. Repetto, L., 2008. Political and judicial checks on corruption: evidence from American state governments. Economics \& Politics, 20(1), pp. 33-61.

30. Repetto, L., 2018. Political budget cycles with informed voters: evidence from Italy. The Economic Journal, 128(116), pp. 3320-3353. https://doi.org/10.1111/ ecoj. 12570

31. US Department of State, 2017. Fiscal transparency report. Washington: US Department of State.

32. Williams, A., 2014. A global index of information and political transparency. University of Western Australia Business School Discussion Paper, No. 14.07.

33. World Bank, 2016. Making politics work for development: harnessing transparency and citizen engagement. Washington: The World Bank. 